BJHS: Themes 4: 99-121, 2019. C B Bitish Society for the History of Science 2019. This is an Open Access article, distributed under the terms of the Creative Commons AttributionNonCommercial-ShareAlike licence (http://creativecommons.org/licenses/by-nc-sa/4.0/), which permits non-commercial re-use, distribution, and reproduction in any medium, provided the same Creative Commons licence is included and the original work is properly cited. The written permission of Cambridge University Press must be obtained for commercial re-use. doi:10.1017/bjt.2019.7 First published online 31 July 2019

\title{
Was this an ending? The destruction of samples and deletion of records from the UK Police National DNA Database
}

\author{
DAVID SKINNER* AND MATTHIAS WIENROTH**
}

\begin{abstract}
Between December 2012 and September 2013 the United Kingdom government oversaw one of the largest destructions of a collection of human-derived samples ever conducted. Approximately 7,753,000 DNA samples and 1,766,000 DNA computerized profiles associated with the UK's policing National DNA Database (NDNAD) were destroyed or deleted. This paper considers this moment of exceptional erasure and the consequent implementation of new processes for routinely discarding and keeping samples and their associated computer records. It is divided into two parts. The first discusses the rapid growth of the NDNAD; the changing legal, ethical and political landscape within which it was promoted and contested; and the developments that led to the decision to limit its scope. The second shifts focus to the operational challenge of implementing the destruction of samples and deletion of records. The NDNAD case allows us to examine the labour and continuing uncertainties involved in erasure of biological data and the emerging norms and practices associated with collecting DNA in differing formats. It also sheds new light on the importance, interconnection and ongoing instability of the ethical and practical biovalue of genetic collections: as the paper argues, far from ending the NDNAD, a more rigorous regime of erasure has helped, for the moment at least, to secure its future.
\end{abstract}

Between December 2012 and September 2013 the United Kingdom (UK) government oversaw one of the largest destructions of human-derived samples ever conducted. Approximately 7,753,000 samples associated with the UK's policing National DNA Database (NDNAD) were destroyed. On 13 December 2012 Lord Taylor of Holbeach, minister for criminal information in the Conservative and Liberal Democrat coalition government, reported this in a Written Ministerial Statement to Parliament as an important step towards the implementation of new legislation, the Protection of Freedoms Act.

* School of Humanities and Social Sciences, Anglia Ruskin University, East Road, Cambridge, CB1 1PT, UK. Email: david.skinner@anglia.ac.uk.

** Policy, Ethics \& Life Sciences Research Centre, School of Geography, Politics and Sociology, Newcastle University, Newcastle upon Tyne, NE1 7RU, UK. Email: matthias.wienroth@newcastle.ac.uk.

This paper happened thanks to the inspiration and encouragement of Jenny Bangham. Jenny, Boris Jardine and Emma Kowal contributed to its development in ways that far exceeded the normal duties of special-issue editors. We would also like to thank the anonymous reviewers whose insightful comments helped us improve the final version. 
Before the Act commences, it is necessary to destroy a significant amount of existing biometric material that the Act would not allow to be retained. The first priority is the destruction of DNA samples. A DNA sample is an individual's biological material, containing all of their genetic information. The Government does not want to retain the complete genetic makeup of any of its citizens. Every DNA sample taken will be destroyed as soon as a DNA profile for use on the database has been obtained from it. ${ }^{1}$

As Taylor also reported, alongside the wholesale destruction of samples, approximately $1,766,000$ computer records containing DNA data - sequences of numbers representing individuals' genetic identities - were to be removed from the NDNAD. Moreover, from this point onwards samples taken during investigations would be routinely destroyed once a computerized profile had been derived from them.

Despite their magnitude, the proposed erasures commanded relatively little public attention and took place without fanfare. This contrasted strikingly with the theatricality and publicity that two years previously had marked the ending of the ill-fated UK Identity Card Register, when approximately five hundred hard-disk drives and a hundred back-up tapes containing the details of fifteen thousand people were magnetically wiped, smashed, shredded and incinerated. Some of this work was done by then Home Office minister Damian Green for the benefit of the attending media. ${ }^{2}$

This paper examines the developments that led to the quiet destruction of DNA samples and the deletion of records, and the consequent reconfiguration of the NDNAD from a distributed, permanent and ever-growing collection of samples and their data doubles to a primarily computer-based resource. Our intention is to draw wider lessons from the NDNAD about the changing meanings of collecting, curating and 'ending' in an era of biobanking, digitalization and surveillance. ${ }^{3}$ The NDNAD case highlights the increasing involvement of the state in the life sciences as a funder, user and also regulator, developing legal and governmental infrastructures for the curation of biodata. Given its status as an instrument of the criminal-justice system with important bearing on life chances and civil liberties, the NDNAD is particularly sensitive to political and legal challenge and contestation. The NDNAD case thus also highlights the differing cultural, legal and ethical standards relating to different sorts of collections and different categories of media in those collections. It also reveals something about 'genetic exceptionalism': 4 in the UK other police repositories of biometric information - fingerprints, footprints, facial images - have not received the same level of concern

1 Home Office and Rt Hon. James Brokenshire, 'James Brokenshire's speech on Chapter 1 of the Protection of Freedoms Act 2012', 2012, at www.gov.uk/government/speeches/james-brokenshires-speech-on-chapter-1of-the-protection-of-freedoms-act-2012, accessed 9 November 2018.

2 Home Office and Rt Hon. Damian Green, 'ID card database destroyed', 2011, at www.gov.uk/ government/news/id-card-database-destroyed, accessed 1 December 2018.

3 Robin Williams and Paul Johnson, 'Circuits of surveillance', Surveillance \& Society (2004) 2(1), pp. 1-14; Michael Lynch, Simon A. Cole, Ruth McNally and Kathleen Jordan, Truth Machine: The Contentious History of DNA Fingerprinting, Chicago: The University of Chicago Press, 2010; Richard Tutton and Mairi Levitt, 'Health and wealth, law and order: banking DNA against disease and crime', in R. Hindmarsh and B. Prainsack (eds.), Genetic Suspects: Global Governance of Forensic DNA Profiling and Databasing, Cambridge: Cambridge University Press, 2010, pp. 85-104.

4 Williams and Johnson, op. cit. (3). 
and attention as the NDNAD. Genetic collections - not just in forensics but also in biomedicine and genealogy - disrupt commonly held distinctions between bodily material and bodily information and their distinct associated cultural, legal and ethical frames. The NDNAD case allows us to examine this disruption, as well as emerging norms and practices associated with holding DNA in differing formats - a full biological sample and a reduced numerical profile - by the state.

By discussing endings in genetic collections, this paper highlights significant gaps in existing academic work on the new life sciences. The copious number of social and historical studies of 'biobanking' contains only a tiny subset of literature on erasures and endings. ${ }^{5}$ In an area driven by notions of growth and promise there is a reluctance to consider the 'failure', lifespan or limitation of projects. ${ }^{6}$ Indeed, operational research suggests that many managers of biobanks are unwilling to plan for the future contingency of dismantling or ending their collections. ${ }^{7}$ Similarly, there is a tendency to conduct academic, ethical and legal debates (including those about desirability and the optimal size of collections) in isolation from the practicalities of the collection, retention, movement and use of materials and information. Only a very few studies consider the care, effort and negotiation required to close or curtail a biobank and the consequent destruction or redistribution of samples. ${ }^{8}$ Similarly, while the rapid growth of national forensic databases has excited considerable debate and critique, this has largely been conducted in isolation from consideration of the practicalities of retention and/or shrinkage. As we will show, the story of the NDNAD is intriguing in part because of what it reveals about the difficulties of enacting the results of legal, political and ethical deliberations about the scope and format of this type of collection, but also how such deliberative infrastructures and discourses can emerge in order to prevent, ameliorate or reframe processes of ending.

After an opening conceptual discussion, this paper is organized in two parts. The first discusses the growth of the NDNAD, the changing ethical and political landscape within which it was promoted and contested, and the developments that led to the decision to limit its scope. The second part shifts focus from ethics, politics and policy making to the operational challenge of the consequent mass destruction of samples and deletion of records and the implementation of new processes for routinely discarding and keeping

5 On the commercial failure of biobanks and ownership of results see Heidi C. Howard, Bartha Maria Knoppers and Pascal Borry Howard, 'Blurring lines: the research activities of direct-to-consumer genetic testing companies raise questions about consumers as research subjects', EMBO Reports (2010) 11(8), pp. 579-582; Ma'n H. Zawati and Amélie Rioux, 'Biobanks and the return of research results: out with the old and in with the new?', Journal of Law, Medicine \& Ethics (2011) 39(4), pp. 614-620.

6 Erik Aarden, 'Projecting and producing "usefulness" of biomedical research infrastructures; or why the Singapore Tissue Network closed', Science and Public Policy (2017) 44(6), pp. 753-762.

7 Jean R. Cadigan, Teresa P. Edwards, Dragana Lassiter, Arlene M. Davis and Gail E. Henderson, “"Forward-thinking” in US biobanking', Genetic Testing and Molecular Biomarkers (2017) 21(3), pp. 148154.

8 Neil Stephens and Rebecca Dimond, 'Closure of a human tissue biobank: individual, institutional, and field expectations during cycles of promise and disappointment', New Genetics and Society (2015) 34(4), pp. 417-436; Stephens and Dimond, 'Unexpected tissue and the biobank that closed: an exploration of value and the momentariness of bio-objectification processes', Life Sciences, Society and Policy (2015) 11(1), pp. 1-15, 14. 
genetic samples and their associated computer profiles. In the concluding remarks, we return to the overarching theme of endings, reflecting on the different dimensions of 'biovalue' that have framed this unprecedented destruction of samples and deletion of profiles. ${ }^{9}$ As we will argue, this case allows wider reflection on varied types and scales of erasure, in particular the different expectations of preservation and ending associated with digital and with corporeal collections. It also highlights the role of forwardlooking imaginaries in contemporary discussions of collections: the potential of DNA to be put to yet-to-be envisaged uses in the future is cited as an argument both for the preservation and for the curtailment of the NDNAD.

\section{Bioinformation, biovalue and forensic DNA databases}

National DNA databases bring together two features of contemporary collecting and archiving: the assembly and use by governments of data about current and potential future populations in their jurisdictions, and the 'banking' of biological information. National forensic databases have features in common with other contemporary genetic collections in biomedicine and science, but the latter collections tend to have been built on voluntary enrolment. By contrast, national forensic DNA databases largely rest on compulsory donation. Concerns about their size draw in part from the seriousness of the implications of the retention of DNA and increased awareness of the troubling ways in which compulsory sampling produces databases that are skewed along lines of age, class, gender and ethnicity. ${ }^{10}$

The development of statistics, computing power and their associated institutions and cadres of experts has a history that stretches back long before the 'information revolution' or recent attention to notions of Big Data. ${ }^{11}$ The NDNAD, however, epitomizes new forms of collecting. As computer and life sciences have become increasingly entangled, forensics, genomics and biometrics depend on the processing of large quantities of bodily and other personal information. ${ }^{12}$ Bronwyn Parry and Beth Greenhough define bioinformation as 'all information, no matter how constituted, arising from the analysis of biological organisms and their behaviour'. ${ }^{13}$ This catch-all definition is, however, very broad; it is helpful for our purposes to consider the specificities of bioinformation that lie in its capacity, also highlighted by Parry and Greenhough, to be 'materialized in different ways at different points in existence' and to operate simultaneously across different data and life-science registers. The translation

9 Robert Mitchell and Catherine Waldby, 'National biobanks: clinical labour, risk production, and the creation of biovalue', Science, Technology \& Human Values (2010) 35(3), pp. 330-355.

10 David Skinner " "The NDNAD has no ability in itself to be discriminatory": ethnicity and the governance of the UK National DNA Database', Sociology (2013) 47(5), pp. 976-992.

11 Elena Aronova, 'Geophysical datascapes of the Cold War: politics and practices of the World Data Centers in the 1950s and 1960s', Osiris (2017) 32(1), pp. 307-327; Dan Bouk, 'The history and political economy of personal data over the last two centuries in three acts', Osiris (2017) 32(1), pp. 85-106.

12 Peter A. Chow-White and Miguel García-Sancho, 'Bidirectional shaping and spaces of convergence: interactions between biology and computing from the first DNA sequencers to global genome databases', Science, Technology, \& Human Values (2012) 37(1), pp. 124-164.

13 Bronwyn Parry and Beth Greenhough, Bioinformation, Cambridge: Polity, 2018, p. 8. 
of biological tissue into manageable 'samples' and 'records' is realized in processes of selection, extraction, organization and stabilization; there is no a priori utility; rather it is created through the labour (and tensions) inherent in the combination and translation between these varied formats.

In the UK and the USA the regulation of holdings of biological material has been shaped in response to a series of human-tissue scandals in the 1980s and 1990s. These related to the storage and exploitation of bodily remains and data without permission from donors. Much of the resulting regulation in the field of biomedicine operates on a distinction between matter derived from the human body and textual information about that material and the persons from which it was extracted. ${ }^{14}$ According to this distinction, human tissue is a unique and finite resource for learning truths about the body, while information can be anonymized, reduced, replicated, shared and interpreted in infinite ways. This distinction between tissue and text is blurred in the case of DNA. For some, DNA has a unique status as the informational essence of the person. As Parry and Cathy Gere have argued, 'In the case of DNA archives we have resources that seem to be both physically and informationally infinite, replicable any number of times without being used up, but also replete with potential for different kinds of analysis.' ${ }^{15}$ This genetic exceptionalism (expressed in key legislation such the UK's Human Tissue Act 2004) makes the NDNAD a particularly interesting case for examining processes of curation, destruction and deletion.

\section{Biovalue}

One advantage of situating the NDNAD and other genetic repositories in wider discussions of collection and curation is that it opens up new questions about how bioinformation comes to be and remain useful and usable in specific contexts. Scholarship on collections reminds us that, in this, ethical governance is not an impediment, or an add-on, but is crucial to the development and maintenance of what Mitchell and Waldby term 'biovalue'. ${ }^{16}$ This concept refers to the inscription of intrinsic value and explicit worth into biomaterials and their various uses (including analysis, retention, expanded/secondary uses and sharing). Biovalue tends to be framed in practical or economic terms; however, these dimensions are dependent on the negotiation of ethical worth expressed in terms of cultural, societal, institutional and individual values, norms, rights, obligations and interests. A crucial consequence of this is that the ethical value of a collection requires continual work and can vary across time and between locations. Collected material risks becoming unusable in a changed social and political context because the original ways in which it was assembled are now deemed unethical. The risk is that a genetic collection will, without an ethical imprimatur,

14 Bronwyn Parry and Cathy Gere, 'Contested bodies: property models and the commodification of human biological artefacts', Science as Culture (2006) 15(2), pp. 139-158.

15 Parry and Gere, op. cit. (14), p. 153.

16 Mitchell and Waldby, op. cit. (9). 
become unusable or, in Emma Kowal's phrase, 'orphan DNA'. ${ }^{17}$ Joanna Radin and Kowal discuss the 'ethical regimes' - bureaucratic structures and systems as well as interpersonal relationships and values - that have facilitated scientific collections. Their comparison of US and Australian cases highlights the effort put into aligning social and technical orders in these regimes; the use of collections of biological material reflects 'variable and mutating' understandings of citizenship, scientific authority and politics. ${ }^{18}$

\section{Forensic DNA databases}

Forensics generally describes the use of scientific methods and technologies for purposes of security and criminal justice, including the investigation of crime. ${ }^{19}$ Since the mid1990s, centrally governed forensic DNA databases have been established around the world. ${ }^{20}$ Police forensic DNA databases are now amongst the largest contemporary repositories of bioinformation. They must be considered both as manifestations of shared legal, policing and scientific practices, and as distinctive national projects that reflect particular understandings of the state and its subjects, security and criminaljustice needs, utility and cost of databasing, and data governance. There are significant points of cooperation and convergence between forensic databases in different countries, but they vary in their history, composition, management and operation. ${ }^{21}$

The development and growth of mass forensic DNA databases is a significant shift in policing practice, ${ }^{22}$ driven by what Robin Williams terms the 'forensic imaginary': a belief in the capacity of science to improve fundamentally the efficiency and accuracy of crime detection. ${ }^{23}$ Investment in databases rests on a powerful scientific and legal

17 Emma Kowal, 'Orphan DNA: indigenous samples, ethical biovalue and postcolonial science', Social Studies of Science (2013) 43(4), pp. 577-597.

18 Joanna Radin and Emma Kowal, 'Indigenous blood and ethical regimes in the United States and Australia since the 1960s', American Ethnologist (2015) 42(4), pp. 749-765.

19 For detailed histories see Paul Johnson, Paul Martin and Robin Williams, 'Genetics and forensics: a sociological history of the National DNA Database', Science Studies (2003) 16(2), pp. 22-37; Michael Lynch, Simon A. Cole, Ruth McNally and Kathleen Jordan, Truth Machine: The Contentious History of DNA Profiling, Chicago: The University of Chicago Press, 2008; Robin Williams and Paul Johnson, 'Wonderment and dread: representations of DNA in ethical disputes about forensic DNA databases', New Genetics and Society (2004) 23(2), pp. 205-223.

20 H.M. Wallace, A.R. Jackson, J. Gruber and A.D. Thibedeau, 'Forensic DNA databases ethical and legal standards: a global review', Egyptian Journal of Forensic Sciences (2014) 4(3), pp. 57-63.

21 Nina Amelung, Filipa Queiros and Helena Machado, 'Studying ethical controversies around genetic surveillance technologies: a comparative approach to the cases of Portugal and the UK', 2017, at https:// estudogeral.sib.uc.pt//handle/10316/41955, accessed 5 November 2018; Victor Toom, 'Forensic DNA databases in England and the Netherlands: governance, structure and performance compared', New Genetics \& Society (2012) 31(3), pp. 311-322; Joelle Vailly, 'The politics of suspects' geo-genetic origin in France: the conditions, expression, and effects of problematisation', BioSocieties (2017) 12(1), pp. 66-88.

22 Victor Toom, 'Producing suspects: the politics of the National DNA Database of England and Wales', Science as Culture (2010) 19(3), pp. 387-391.

23 Robin Williams, 'DNA databases and the forensic imaginary', in Hindmarsh and Prainsack, op. cit. (3), pp. 131-152. 
consensus about the reliability of DNA matching to resolve questions of identity. ${ }^{24}$ National forensic databases entail more than this, however: they are, using the terminology of the introduction to this special issue, 'working collections' that enable continual population surveillance via the speculative searching of genetic data in the hope of matching a database profile to crime-scene DNA. ${ }^{25}$ People under genetic surveillance have two existences: both as a corporeal entity and as a computerized 'data double'. ${ }^{26}$ In the operation of forensic DNA databases this is expressed in two related forms of curation, the processing and storage of the human samples and other traces collected from crime scenes, and the management of computerized profiles derived from those samples. The headline term 'database' can obscure the complex, heterogeneous and distributed systems involved in, for example, the extraction of samples, their movement and storage and their computerization.

Within this context, the biovalue of forensic collections is constituted not only in their effectiveness in solving or preventing crime but also through professional standards, legal frameworks and ethical legitimacy. Forensic collections have developed over time through a combination of serendipity and purposive sampling focused on shifting understandings of 'suspect populations'. Their growth has - at different times and places - prompted a range of ethical concerns. These relate to the sizes of databases; their contributions to security and criminal justice; what the appropriate criteria might be for collection, retention and use of samples and data; and how best to address questions of the privacy and ownership of those samples and data. Consequent debates have often centred on two troubled concepts: (i) the notion that it is possible and desirable to achieve a 'balance' between state power and civil liberties, and (ii) in achieving that balance, the notion that the size and criteria of databases should be 'proportionate' to their risks and benefits. ${ }^{27}$

Given this paper's focus on the role of archiving, preserving and ending of collections, it is helpful to reflect on the multiple notions of time in this story. Forensic DNA databases have been promissory objects, driving expectations of better outcomes in the future. Criteria for inclusion in databases generally relate to prior contact with the criminal-justice system - typically arrest, prosecution or conviction for a crime. The retention of DNA is justified on the basis of an anticipated heightened risk of future serious criminal behaviour. Thus underlying the development of forensic databases are forwardlooking predictive, deterrent and precautionary logics that fold into other assumptions

24 Johnson, Martin and Williams, op. cit. (19); Lynch et al., op. cit. (3); Toom, op. cit. (21); Robin Williams and Matthias Wienroth, 'Identity, mass fatality and forensic genetics', New Genetics and Society (2014) 33(3), pp. 257-276.

25 Robin Williams and Matthias Wienroth, 'Social and ethical aspects of forensic genetics: a critical review', Forensic Science Review (2017), 29(2), pp. 145-170.

26 Kevin D. Haggerty and Richard V. Ericson, 'The surveillant assemblage', British Journal of Sociology (2000) 51(4), pp. 605-622.

27 Robin Williams and Paul Johnson, 'Inclusiveness, effectiveness and intrusiveness: issues in the developing uses of DNA profiling in support of criminal investigations', Journal of Law, Medicine \& Ethics (2006) 33(3), pp. 234-247. 
about past behaviour justifying the continuing curtailment of civil liberties. ${ }^{28}$ In addition, the recording of people on the database is, in some cases, itself assumed to act as a deterrent to future criminal activity, although there is no evidence for such an effect.

\section{The NDNAD: growth and challenge}

The UK National DNA Database (NDNAD), operational from April 1995, was one of the first forensic databases in the world. It remains one of the largest (certainly per capita) and most-accessed. The NDNAD is managed by the Home Office and holds genetic records from all police forces in England and Wales, and from the police DNA databases in Scotland and in Northern Ireland.

The Police and Criminal Evidence Act (PACE) 1984 enabled the police to take samples from persons charged with 'serious arrestable' offences, initially ad hoc forensic blood tests. In 1989, the Home Affairs Select Committee called for the establishment of a DNA database '[o]nce a method of encoding DNA profiles has been established [and] provided that the expensive computer equipment [is] available'. ${ }^{29}$ The NDNAD was made technically possible by the discovery and subsequent development of short tandem repeat (STR) polymorphisms as biomarkers from 1991.30 These biomarkers, also called loci, are encoded as a string of standardized numbers, the DNA profile, which can be stored easily and made searchable for comparison with DNA profiles generated from traces found at crime scenes and from other sources, including other DNA databases, and databanks of biological material. ${ }^{31}$

The Criminal Justice and Public Order Act (CJPOA) 1994 provided the legislative basis for the NDNAD, giving police the power to collect, without individual consent, DNA samples from persons charged with a 'recordable' offence. While, previously, DNA collection included drawing of blood, the taking of DNA via a swab of the inner cheek now became available and was deemed a 'non-invasive' procedure. ${ }^{32}$ The CJPOA also legislated for the indefinite retention of DNA profiles from persons convicted of recordable offences, while at the same time required the destruction of samples and profiles of all those not convicted or cautioned once the investigation had ended. ${ }^{33}$ The NDNAD, therefore, began as a collection of samples taken from crime

28 Martin Innes and Alan Clarke, 'Policing the past: cold case studies, forensic evidence and retroactive social control', British Journal of Sociology (2009) 60(3), pp. 543-563.

29 House of Commons Select Committee on Science and Technology, 'Science and technology: seventh report (session 2004-05)', 2005, at https:/publications.parliament.uk/pa/cm200405/cmselect/cmsctech/96/ 9602.htm, accessed 1 May 2019.

30 Albert Edwards, Andrew Civitello, Holly A. Hammond and C. Thomas Caskey, 'DNA typing and genetic mapping with trimeric and tetrameric tandem repeats', American Journal of Human Genetics (1991) 49(4), p. 746.

31 John M. Butler, Forensic DNA Typing: Biology, Technology, and Genetics of STR Markers, Burlington, MA: Academic Press, 2005, pp. 85-122.

32 In some other countries the taking of a mouth swab is considered invasive and requires donor consent. For discussion of the French example see Vailly, op. cit. (21).

33 Robin Williams and Paul Johnson, Genetic Policing: The Use of DNA in Criminal Investigations, Cullompton: Willan Publishing, 2008. 
scenes and from persons, and of profiles derived from these samples. It was a distributed system where samples would be stored in what were essentially small local cryogenic biobanks held by the police forces that had collected the samples and by forensic service providers (FSPs) - including the national Forensic Science Service (until 2012) and non-state providers, notably LGC Ltd, Orchid Cellmark Ltd, and Key Forensic Services Ltd - who analysed and stored them. DNA profiles, on the other hand, would be held in a central digitized database.

\section{'Virtually the entire active criminal population': rapid expansion}

The rapid expansion of the NDNAD was driven both by then world-leading British forensic science, enabling novel ways of using DNA, and, from the year 2000 onwards, by the political will to profile 'virtually the entire active criminal population' ${ }^{34}$ These led to a concerted infrastructural investment by successive Labour governments via the DNA Expansion Programme and the Forensic Integration Strategy. ${ }^{35}$ The initial growth of the NDNAD had taken place at a time when recorded offences were falling but fear of crime was intensifying: these were accompanied by new responses by the police and courts to crime and other kinds of emerging security threats. ${ }^{36}$ The flip side of hopes for genetics was therefore growing fear of disorder, crime and terrorism and, debatably, government attempts to 'govern through crime'. ${ }^{37}$ The expansion of the NDNAD fitted well with central preoccupations of the then self-styled New Labour government's law and order project: being 'tough on crime', tackling 'antisocial behaviour' and 'managing risk'. This period saw more spending on policing and an increased volume and reach of legislation. In both cases, we can see a widening of focus from problems of crime to the prevention of social disorder.

Early in the development of the NDNAD there were a number of significant legal cases which raised concerns about the grounds under which a genetic sample could be retained and used as evidence. ${ }^{38}$ These challenges were ultimately overruled in the courts, reflecting a growing consensus not only about the reliability of genetic identification but also that the NDNAD was an important tool for the management of crime. Under the DNA Expansion Programme the population of the database grew from $c .737,000$ to 5,617,604 subject profiles between 2000 and 2008 .

As Table 1 sets out, a series of legislative changes provided the basis for this rapid growth. The changes enabled the ever-broader collection and indefinite retention of DNA samples and profiles under a wider range of circumstances. These included

34 Tony Blair in 2000, as cited by Helen Wallace, 'The UK National DNA Database: balancing crime detection, human rights and privacy', EMBO reports (2006) 7(1S), pp. 26-30.

35 Williams and Johnson, op. cit. (3); Carole McCartney, 'The DNA expansion programme and criminal investigation', British Journal of Criminology (2005) 46(2), pp. 175-192.

36 Carole McCartney, Robin Williams and Tim Wilson, The Future of Forensic Bioinformation, London: Nuffield Foundation, 2010.

37 Simon A. Cole, 'How much justice can technology afford? The impact of DNA technology on equal criminal justice', Science and Public Policy (2007) 34(2), pp. 95-107.

38 Williams and Johnson, op. cit. (3). 
Table 1. The expanding database - enacted DNA inclusion and retention.

\begin{tabular}{|c|c|c|c|}
\hline Legislation & Inclusion criteria & Retention & $\begin{array}{l}\text { Number of DNA } \\
\text { records* }\end{array}$ \\
\hline $\begin{array}{l}\text { Criminal Justice and } \\
\text { Public Order Act } \\
\text { (CJPOA) } 1994\end{array}$ & $\begin{array}{l}\text { Cautioned for or } \\
\text { convicted of a } \\
\text { qualifying offence }\end{array}$ & $\begin{array}{l}\text { Indefinite retention (profiles) } \\
\text { Deletion of all other profiles } \\
\text { after investigation or } \\
\text { prosecution }\end{array}$ & $\begin{array}{l}1,611,445 * \\
\text { (31 March 2002) }\end{array}$ \\
\hline $\begin{array}{l}\text { Criminal Justice \& } \\
\text { Police Act (CJPA) } \\
2001\end{array}$ & $\begin{array}{l}\text { Charged with a } \\
\text { qualifying offence } \\
\text { Volunteering a sample }\end{array}$ & $\begin{array}{l}\text { Indefinite retention (profiles and } \\
\text { samples) } \\
\text { Inability to withdraw consent } \\
\text { once given }\end{array}$ & $\begin{array}{l}2,099,964 * * * \\
(31 \text { March 2003) }\end{array}$ \\
\hline $\begin{array}{l}\text { Criminal Justice Act } \\
\text { (CJA) } 2003\end{array}$ & $\begin{array}{l}\text { Arrested for a } \\
\text { qualifying offence } \\
\text { Volunteering a sample }\end{array}$ & $\begin{array}{l}\text { Retention from age ten until age } \\
100\end{array}$ & $\begin{array}{l}3,085,766 * * * * \\
(31 \text { March 2005) }\end{array}$ \\
\hline $\begin{array}{l}\text { Serious Organised } \\
\text { Crime and Police } \\
\text { Act (SOCA) } 2005\end{array}$ & $\begin{array}{l}\text { Identification of } \\
\text { deceased, and of } \\
\text { body parts }\end{array}$ & & $\begin{array}{l}4,428,376 * * * * * \\
(31 \text { March 2007) }\end{array}$ \\
\hline
\end{tabular}

Notes:

* Cf. GeneWatch UK (2010), who point out that approximately 10 per cent of listed figures will be made up of replicates: www.genewatch.org/uploads/f03c6d66a9b354535738483c1c3d49e4/UK_DNA_detections. pdf, accessed 17 April 2018.

** Derived from data provided in the National DNA Database, 'Annual Report 2002-03', p. 11, at www. genewatch.org/uploads/f03c6d66a9b354535738483c1c3d49e4/NDNAD_Annual_Report_02_03.pdf, accessed 1 May 2019.

$* * *$ The National DNA Database, op. cit., p. 11.

$* * *$ The National DNA Database, 'Annual Report 2004-2005', figure on p. 6, retention data on pp. 34-35, at www.genewatch.org/uploads/f03c6d66a9b354535738483c1c3d49e4/NDNAD_AR_04_05.pdf, accessed 1 May 2019.

$* * * *$ The National DNA Database, 'Annual Report 2006-2007', p. 2, at www.gov.uk/government/publications/ndnad-annual-reports, accessed 1 May 2019.

people charged with a recordable offence but either not prosecuted or later cleared, those arrested for a recordable offence (from the age of ten) independent of further prosecution, those deceased, those from whom a body part originated for identification purposes, those volunteers participating in police mass screenings or elimination checks, and those issued with a penalty notice for disorder. Under the Terrorism Act 2000 and the Anti-terrorism, Crime and Security Act 2001 (implemented in the aftermath of the 9/11 attacks in the USA), the NDNAD also expanded to hold the genetic records of suspects defined under the Schedule 7 procedure of counterterrorism legislation.

By 2009, the NDNAD held records approximating 10 per cent of the population of England and Wales and in the process had expanded beyond its original remit to profile the criminally active population. As it grew rapidly, its advocates emphasized its broad potential to support fast and robust identification of suspects, but also to help exonerate those found not to be guilty, to reduce investigative costs and to offer 
a deterrent to (would-be) criminals. ${ }^{39}$ Criminal-justice stakeholders not only successfully argued for the merits of using biological materials on databases for security and justice purposes, but also made the case to government and Parliament for the ongoing, future benefits of mass DNA retention. Continuing innovation in the field of forensic genetics supported expectations that the capacity and value of the NDNAD would only grow. This fuelled a belief that a larger database would provide better outcomes in terms of justice and social order. In other words, during the initial expansionary phase the biovalue of the NDNAD rested on compelling claims as to its current and future utility as a means of managing crime and disorder: claims that initially bypassed questions about the ethical or economic value of an ever-growing database. However, the significant expansion generated an increasingly high-profile discourse of contestation around the NDNAD.

\section{'Eroding public trust in policing': sustaining legitimacy}

Relating to the retention regime, critical commentators pointed to concerns over proportionality, individual privacy and dignity, and equality, as well as to the NDNAD's lack of transparent governance. In addition, many challenged assertions of enhanced crime control derived from the existence and growth of such databases. ${ }^{40}$ One of the most active critics of the NDNAD at that time was GeneWatch UK, a not-for-profit organization that monitored genetic developments of public interest, and extended its original focus of genetics in agriculture and medicine to the forensic domain in the early 2000s. The organization provided in-depth commentaries and information on the NDNAD, ${ }^{41}$ significantly contributing to the public debate around the rapid expansion of the database. Its director, Helen Wallace, said in 2009, 'The massive expansion of Britain's DNA database has failed to deliver genuine benefits in terms of solving crime, instead eroding public trust in policing' ${ }^{42}$

Contestations such as these had a particular flavour and momentum in part because the initial establishment and development of the database took place with little public discussion or statutory regulation. ${ }^{43}$ As a result, the UK government's Home Office,

39 For example Lyn Fereday (ed.), 'Transforming the use of forensics through the DNA Expansion Programme: beyond DNA in the UK - integration and harmonisation', Newport, South Wales: Home Office Science Policy Unit, 2004; Home Office, 'Keeping the right people on the DNA database', 2009, at http://data.parliament.uk/DepositedPapers/Files/DEP2009-2788/DEP2009-2788.pdf, accessed 1 May 2019; House of Commons Select Committee on Science and Technology, op. cit. (29).

40 For example, Anthony M. Cutter, 'To clear or to convict? The role of genomics in criminal justice', Genomics, Society and Policy (2006) 2(1), pp. 1-15; Kristina Staley, The Police National DNA Database: Balancing Crime Detection, Human Rights and Privacy, Windsor: GeneWatch UK, 2005; Carole McCartney, 'The DNA expansion programme and criminal investigation', British Journal of Criminology (2006) 46(2), pp. 175-192; Nuffield Council on Bioethics, 'The forensic use of bioinformation: ethical issues', 2007, available at http://nuffieldbioethics.org/project/bioinformation, accessed 1 May 2019.

41 'The UK Police National DNA Database', at www.genewatch.org/sub-539478, accessed 12 December 2018.

42 'GeneWatch PR: response to government DNA proposals', at www.genewatch.org/article.shtml?als[cid] $=564539$ \&als [itemid] $=565571$, accessed 1 December 2018 .

43 Dana Wilson-Kovacs, David Wyatt and Christine Hauskeller, “"A Faustian bargain?” Public voices in forensic DNA technologies and the National DNA Database', New Genetics and Society (2012) 31(3), pp. 285-298. 
and the NDNAD Strategy Board, found themselves needing to reassert the legitimacy of the NDNAD. Increasingly they made claims of utility and proportionality through mechanisms such as the National DNA Database annual report (with the first publicly accessible report published in 2007). ${ }^{44}$ Initially, however, the primary response to concerns was the development of formal governance structures that emphasized the similarity of the forensic database to biomedical biobanks and enrolled new epistemic communities outside forensic science, from philosophy, medicine and research ethics, as well as from law and criminology, to manage public concerns. ${ }^{45}$ This included the formation, in 2007, of the role of the Forensic Science Regulator, ${ }^{46}$ focused on ensuring the effectiveness of the criminal-justice system through UK forensic science services, and of the NDNAD Ethics Group. Both were set up as advisory non-departmental public bodies tasked with providing advice to the Home Office. The Ethics Group focused on exploring the impact on society of DNA retention and uses. The first report by the group, in 2008, stated that it sought to 'balance the interests of public protection through the forensic use of DNA with the inevitable invasions of privacy and personal labelling that this causes'. ${ }^{47}$

In late 2007, the UK's non-governmental equivalent to a national ethics commission, the Nuffield Council on Bioethics, published The Forensic Uses of Bioinformation: Ethical Issues. This report argued for a rights-based approach in the balance of public security and personal liberty, and raised concerns about the rapid expansion of police rights to take, retain and use biomaterials from individuals. In 2009, the UK Human Genetics Commission (HGC), an advisory non-departmental public body, delivered its report, Nothing to Hide, Nothing to Fear?. The HGC drew on insights from two public engagement projects which highlighted the widely perceived novelty of the NDNAD and inconsistencies in the way that the database was governed. It proposed strengthening the role of the NDNAD Ethics Group, and recommended establishing an independent oversight body for the use of biological material in the criminal-justice system. These developments reflected emerging recognition of a special status of the NDNAD as population surveillance tool and, in the light of public awareness of its existence and scale, the need for further and continuous scrutiny of its curation practices.

\section{'Adopt the protections of the Scottish model': how to shrink the NDNAD?}

As public and policy debate about the NDNAD continued, a landmark ruling by the European Court of Human Rights (ECtHR) in $S \&$ Marper v. UK (2008) stated that

44 Collected at 'National DNA Database documents', at www.gov.uk/government/collections/dnadatabase-documents.

45 Tutton and Levitt, op. cit. (3), p. 95.

46 Forensic Science Regulator, 'Forensic Science Regulator, business plan: 2008 to 2009 and 2010 to 2011', 2008, at www.gov.uk/government/collections/forensic-science-regulator-newsletters-and-reports, accessed 1 May 2019.

47 The NDNAD Ethics Group, '1st annual report of the Ethics Group: National DNA Database', 2008, at https://assets.publishing.service.gov.uk/government/uploads/system/uploads/attachment_data/file/117615/ NDNAD_Ethics_Group_Annual_Report.pdf. 
the indefinite retention of biometric data from non-convicted persons for criminal-justice purposes violated Article 8 of the European Convention on Human Rights. The two complainants had unsuccessfully attempted to get their records deleted from UK national databases after acquittal. The ECtHR took a different view to the UK courts and argued that

the blanket and indiscriminate nature of the powers of retention of the fingerprints, cellular samples and DNA profiles of persons suspected but not convicted of offences ... fails to strike a fair balance between the competing public and private interests and that the respondent State has overstepped any acceptable margin of appreciation in this regard.

The verdict gave particular weight to the argument that DNA presents a unique genetic code, and that 'retention of cellular samples is particularly intrusive given the wealth of genetic and health information contained therein'. ${ }^{48}$

It was to be four years before the UK fully implemented the ECtHR's ruling. A number of factors contributed to this delay, including operational concerns about its practicality and, in 2010, a change of government. There is no doubt, however, that initially the Labour government sought a slow and in some respects minimal response to the judgment. In May 2009, six months after the decision by the ECtHR, the Home Office announced a consultation process, with the publication of the hundred-page document 'Keeping the right people on the DNA database'. Its objective was to 'develop a DNA framework which has the support and confidence of the public and achieves a proportionate balance between the rights of the individual and protection of the public' ${ }^{49}$ In some ways the Home Office proposals set out in this document exceeded the ECtHR ruling as they envisaged the destruction of DNA samples that had been taken from suspects on arrest, following the creation and upload of a computerized DNA profile. As such, the Home Office was indirectly proposing a reduction of the distributed database and of the local retention of crime-scene samples, focusing instead on a centralized computer database of electronic DNA profiles. The consultation document also noted that since the verdict by the ECtHR, DNA of children under ten on the database had been removed, and would not be stored again in the future. Aside from these instances, however, in other respects the Home Office sought to minimize the ECtHR judgment by arguing for the importance of sufficient time to consider deletions, and offering a raft of evidence to support their proposal that all DNA profiles should be retained for six years (and in some cases for twelve years), even if the donor had not been convicted of a crime.

The consultation engendered significant public debate. Although the ECtHR judgment related to the retention of both fingerprints and DNA, this discussion focused almost exclusively on the genetic database, and in particular the criteria to be used for retention of computerized profiles. Broadsheet newspapers, notably The Guardian, The Independent and the Daily Telegraph, took a sustained interest in this issue. Civilsociety groups such as Liberty, GeneWatch UK, Black Mental Health and the

48 ECtHR 1581 (2008) para. 120.

49 Home Office, op. cit. (39), p. 4. 
Runnymede Trust voiced concerns over the limited extent of changes offered by the Home Office. The director of the civil rights group Liberty, Shami Chakrabarti, viewed the proposals as not 'necessarily a complete two fingers to the court of human rights but it comes pretty close'. ${ }^{50}$ Key public bodies, including the Northern Ireland Human Rights Commission and the Nuffield Council on Bioethics, also raised concerns. The latter challenged government data underlying the proposed new retention periods for arrestees and cited findings of its 2007 report on the lack of evidence that retaining DNA profiles from the non-convicted would significantly support crimedetection rates. They also critiqued the lack of oversight and transparency in the proposed regime. ${ }^{51}$

The Labour government had originally planned to enact its proposals without developing primary legislation, by delegating powers to ministers to regulate the retention, use and destruction of forensic materials. However, reports in 2009 by the House of Lords Select Committee on the Constitution and Parliament's Joint Committee on Human Rights both judged this approach unacceptable because of the importance of the issue of retention of samples and profiles. In a Westminster Hall debate in late 2009, called by then backbench Labour MP Diane Abbott, Abbott argued,

The DNA database is an extraordinary innovation, which has emerged sideways and incrementally, without the full glare of parliamentary scrutiny, yet we have the biggest DNA database per head of population in the world. It is extraordinary that a project with such ramifications has not had the parliamentary scrutiny that it deserves. ${ }^{52}$

Eventually, in the last months of the Labour government, the proposed changes received parliamentary scrutiny as part of the Crime and Security Bill. This proposed the eventual destruction of all samples once a computerized profile had been derived and also six-year (or in some specific cases twelve-year) retention of the profiles of adults arrested but not convicted. The government argued that these criteria meant it had six years from the passing of the legislation to destroy the current collection of samples and remove the profiles of the innocent from the database, although it anticipated that in practice this could be completed by 2012 .

The Crime and Security Act 2010 progressed through Parliament but its implementation was curtailed by the defeat of Labour in the 2010 general election, and the arrival of the new coalition government whose approach reflected different priorities. The Liberal Democrats and some MPs from the libertarian wing of the Conservative Party had been at the forefront of criticism of what they termed the growing 'database state'. This coincided with another policy imperative, the desire to cut spending, and to reform supposedly inefficient public services, including the policing and forensic services. The Coalition Agreement committed to 'adopt the protections of the Scottish model of

50 BBC, 'Time limits on innocent DNA data', 2009, at http://news.bbc.co.uk/1/hi/uk/8037042.stm.

51 An archive of the manner of the responses to the consultation are collected at 'Home Office DNA consultation', at www.genewatch.org/sub-564539, accessed 1 May 2019.

52 Diane Abbott, 'Parliamentary debate on the DNA database', 2009, at www.dianeabbott.org.uk/news/ speeches/news.aspx? $\mathrm{p}=102558$. 
DNA retention' for the NDNAD; ${ }^{53}$ the Scottish DNA database only retained DNA of people convicted of offences. The coalition government's Protections of Freedom Bill amended the Crime and Security Act and proposed an alignment between England and Wales and the Scottish model, requiring the deletion of all profiles of non-convicted donors. The new bill also regularized and strengthened the governance and oversight of the NDNAD, placing the NDNAD Strategy Board on a legal footing, and establishing the Office of the Commissioner for the Retention and Use of Biometric Material. The bill became law in 2012 but not without opposition. The shadow home secretary, Yvette Cooper, claimed, 'They are going too far on DNA retention and are going against the evidence that shows it has a significant impact bringing serious criminals to justice and exonerating innocent people.' 54

\section{Reconfiguring the NDNAD: exceptional and operational erasures}

Although framed as a response to the ECtHR judgment, the retention and governance regime that emerged from the Crime and Security Act 2010 and the Protection of Freedoms Act (PoFA) 2012 went further than the ECtHR judgment required. A wider set of concerns about the value and legitimacy of the database coalesced around this legal response; these were practical (what is the most effective size and composition of the database?), ethical (what is proportionate?) and economic (what is affordable?). The elements of the PoFA relating to the NDNAD included the requirement to destroy samples, cull a significant proportion of computerized profiles, and develop new procedures for handling arrestee DNA in the future. With the development and debate of the PoFA, discussions about the appropriate size and operation of the NDNAD largely came to an end, but the Act had to be implemented and this required negotiation and labour, not least in relation to questions of erasure.

At crunch points, practices of retention are scrutinized and open up potential revisions in the modi operandi or continuing existence of collections. In the implementation of the PoFA, we can identify three types of 'ending' that are of wider relevance to the discussion of collections. (1) The PoFA prompted an existential destruction of almost the entire collection of retained samples. (2) It required the exceptional one-off erasure of whole categories of computerized profiles. (3) The Act also addressed a type of collection management that might be termed normal, or everyday, deletion: this term refers to the ongoing, routine erasures integral to the efficient and compliant operation of most biodata collections. These 'daily deaths' keep the overall archive structure alive. In the case of the NDNAD, these endings include the deletions of locally held data once it has been uploaded into the national system. They also include 'housekeeping' deletions that, also in the name of efficiency, tidy up anomalies. As the database grew, this became a significant issue. In 2008, the National Police Improvement Agency estimated that

53 HM government, 'The coalition: our programme for government', 2010, https://assets.publishing.service. gov.uk/government/uploads/system/uploads/attachment_data/file/78977/

coalition_programme_for_government.pdf, p. 11, accessed 6 November 2018.

54 Ian Dunt, 'A new day for civil liberties? Coalition published freedom bill,' 11 February 2011, at www. politics.co.uk/news/2011/2/11/a-new-day-for-civil-liberties-coalition-publi, accessed 5 November 2018. 
13-14 per cent of all the records on the NDNAD were 'replicates', created when a genetic profile was loaded onto the database on more than one occasion. Replication could occur - the agency explained - 'if the same person provided different names, or different versions of their name, on separate arrests, or because profiles are upgraded'. ${ }^{55}$ Between 2008 and 2012 considerable work had been put into reducing rates of replication, and anecdotal reports suggest that the PoFA implementation presented another opportunity to achieve this. Prior to the PoFA, although most DNA profiles and samples were held indefinitely, the law stipulated that certain categories of record must be deleted after use. These included those derived from samples voluntarily donated by the public or police during an investigation for elimination purposes. Questions about when to preserve or erase genetic samples and their data doubles had been, therefore, part and parcel of the operation of the NDNAD prior to the PoFA. But the PoFA required more rigorous, varied and complicated forms of ending. The sections that follow draw on publicly available NDNAD monitoring and governance documentation and remind us that endings - be they existential, exceptional or everyday - are easier said than done, requiring considerable organizational and operational energy.

The shift in tone and focus - from a discussion of ethics, policy and legislation to that of implementation - is reflected in the Home Office's 'Impact Assessment' of the proposed changes. These documents associate ending (part of) the NDNAD collection with financial savings - they contrast the cost of destroying a DNA sample (three pence) with the annual cost of retaining a sample (ninety pence). But they also detail significant additional costs to this destruction:

There would be a cost of around $£ 300 \mathrm{k}$ to reprogram the computer software to delete DNA profiles and fingerprint records. It would cost $£ 4.3 \mathrm{~m}$ to delete orphaned profiles. We estimate that to destroy DNA samples would cost around $£ 188 \mathrm{k}$ (one-off) plus a small amount per year thereafter, while re-sampling those re-arrested (whose data would previously have been retained) will cost approximately $£ 2.3 \mathrm{~m}$ annually. To destroy paper records of fingerprints would cost around $£ 6.0 \mathrm{~m}$ (one-off) and $367 \mathrm{k} /$ year. There will also be a cost of $£ 500 \mathrm{k}$ per annum to cover the operating costs of the independent Commissioner for the Retention and Use of Biometric Material. ${ }^{56}$

The implementation of the PoFA also required an agreed set of terms and definitions that allowed a clear discursive and operational disaggregation of samples of bodily material and computerized genetic profiles. A new official vocabulary distinguished a catch-all category of 'DNA data' and within that subcategories of 'DNA sample', 'DNA profile' and 'associated data', ${ }^{57} \mathrm{~A}$ variety of different actors were drawn into the conduct and monitoring of sample destruction and profile deletion. These include the NDNAD Strategy Board, the Ethics Group, the new biometrics commissioner,

55 House of Commons Home Affairs Committee, A Surveillance Society? Fifth Report of Session 2007-08, vol. 1, London: The Stationery Office, 2008, p. 78.

56 Home Office, 'Retention of DNA \& fingerprints by police impact assessment', 2011, at www.parliament. uk/documents/impact-assessments/IA12-004B.pdf, p. 2.

57 Home Office NDNAD Delivery Unit (NDU), 'The NDNAD Strategy Board policy for access and use of DNA samples, profiles and associated data', 2015 at www.gov.uk/government/publications/access-and-use-ofdna-samples-profiles-and-associated-data, accessed 4 July 2019. 
the United Kingdom Accreditation Service together with the Forensic Science Regulator (who accredited and audited UK forensic science providers), the policing National Delivery Unit, the Association of Chief Police Officers (now the National Police Chiefs' Council), and the Police National Computer.

\section{'Not a simple matter': the existential destruction of samples and exceptional deletion of profiles}

The governance documentation (including reports by the biometrics commissioner, reports and minutes of the Strategy Board and reports by the Association of Chief Police Officers Criminal Records Office (ACRO)) has copious detail on the policies and procedures for the operational management of the NDNAD. By contrast, there is surprisingly little detail about the mass erasure of samples and profiles. A recent academic analysis of the implementation of the PoFA based on a systematic review of this documentation mirrors this omission, making only passing mention of sample destruction. ${ }^{58}$

Although the PoFA passed into law in May 2012, its 'biometric' provisions relating to DNA and fingerprints were not brought into effect until 31 October 2013. In the meantime, a wide-ranging 'cleansing' exercise was coordinated by the Home Office, with a view to ensuring that material would not be wrongfully held when those provisions came into effect, and that DNA records would not be wrongly erased. ${ }^{59}$ The NDNAD Strategy Board declared,

The implementation of the Protection of Freedoms Act is not a simple matter, involving significant preparatory work and complex reprogramming of databases to ensure that each person's DNA and fingerprints are removed or retained correctly and at the right time. ${ }^{60}$

The existential destruction of the collection of DNA samples presented a number of logistical challenges. One was that neither samples nor data were stored in a single place. The distributed character of the forensic system inevitably meant that individual police forces would hold biological material. In 2012-13, most forensic DNA samples were processed by and retained on behalf of the police by three independent private forensic science providers: LGC Ltd, Orchid Cellmark Ltd and Key Forensic Services Ltd. The destruction of samples on the premises of the three forensic science providers is reported to have begun in December 2012. However, there is scant information as to how this was conducted beyond the insight that it took place in batches at weekends (presumably in order not to interfere with the normal workings of the three laboratories where the samples were held). The biometrics commissioner reported 'no reason to doubt the accuracy' of ministerial claims that the destruction of samples had been

58 Aaron Opoku Amankwaa and Carole McCartney, 'The UK National DNA Database: implementation of the Protection of Freedoms Act 2012', Forensic Science International (2018) 284, pp. 117-128.

59 Office of the Biometrics Commissioner, Annual Report 2014, at https://assets.publishing.service.gov.uk/govern ment/uploads/system/uploads/attachment_data/file/387601/45428_Biometrics_Annual_Report_ACCESSIBLE.PDF, accessed 5 November 2018.

60 NDNAD Strategy Board, 'NDNAD annual report 2011-12', 2013, at http://data.parliament.uk/ DepositedPapers/Files/DEP2013-0834/NDNADAnnualReport2011-12.pdf, accessed 5 November 2018. 
completed in compliance with legislation. The basis for that confidence rested to some extent on the expectation of significant savings to forensic science providers if they no longer had to offer the mass cold storage of samples:

The costs associated with the storage of millions of DNA samples were substantial and neither FSPs [forensic science providers] nor police forces had or have a significant commercial incentive to store large numbers of samples which could and should be destroyed. In those circumstances - and quite apart from the legal, reputational and other risks that would have been involved if they had continued to hold samples when it was unlawful for them to do so - it would perhaps be surprising if FSPs or forces had deliberately chosen not to comply with the new retention/destruction regime. ${ }^{61}$

Whatever its logistical challenges, a benefit of the post-PoFA sample retention regime was that the blanket criteria for destruction were relatively straightforward. In contrast, delineating the category of computerized profiles of 'the innocent' in order to carry out exceptional erasures was a more complex matter. To achieve this the NDNAD Strategy Board outlined a phased approach to the mass deletion of profiles from the NDNAD computer system (outlined in Table 2). A crucial issue was the need to check the past arrest and conviction records held on the Police National Computer (PNC) against those on the NDNAD. The order in which categories of profile were deleted reflects the relative ease or difficulty of identifying records for erasure.

\section{'An impossible task': the new retention schedule}

As Table 2 suggests, the PoFA established a more complex regime for the retention of DNA profiles and created a new category of records for routine, everyday deletion: those of people arrested who were, however, at the end of the investigation, not charged or else were charged but not convicted. In addition, certain categories of records now had limited retention times (Table 3). The difficulty of implementing the new 'complicated' rules of retention and deletion was highlighted by the biometrics commissioner in his 2014 report:

When the general rule is that all DNA profiles and fingerprints can be retained indefinitely, the implementation of a retention regime is simple. However, when one is dealing with hundreds of thousands of arrestees each year - and when retention or deletion of their DNA profiles and fingerprints turns on the specific history of each individual arrestee - the implementation problems are considerable. ${ }^{62}$

This required the development of new technical, legal and professional roles and protocols to define, operationalize and audit both 'innocence' and 'deletion'.

The PoFA allowed the police to take DNA samples from all persons arrested for a recordable offence but stipulated that these samples should be routinely destroyed once a profile has been derived and uploaded to the database. Police were, however, allowed to keep DNA samples until six months after a criminal investigation and

61 Office of the Biometrics Commissioner, op. cit. (59), p. 62.

62 Office of the Biometrics Commissioner, op. cit. (59), p. 5. 
Table 2. Exceptional mass deletions of profiles from the NDNAD computers

\begin{tabular}{lll}
\hline \hline Action & Completed & Deletions \\
\hline $\begin{array}{l}\text { Deletion of profiles where no link with the PNC could be established } \\
\begin{array}{l}\text { Deletion of profiles belonging to individuals with a single arrest against } \\
\text { their name for which no further action was taken }\end{array}\end{array}$ & $\begin{array}{l}\text { February 2013 } \\
\text { April 2013 }\end{array}$ & 504,000 \\
$\begin{array}{l}\text { Deletion of profiles belonging to individuals with a single arrest against } \\
\text { their name where further action was taken, but there is no power to retain } \\
\text { their DNA }\end{array}$ & June 2013 & 204,000 \\
$\begin{array}{l}\text { Deletion of profiles belonging to individuals with more than one arrest but } \\
\text { no convictions or other circumstances which allow their DNA to be } \\
\text { retained }\end{array}$ & September 2013 & 426,000 \\
\hline \hline
\end{tabular}

Source:

Home Office, 'NDNAD Strategy Board annual report 2012-13', 2013, at https://assets.publishing.service. gov.uk/government/uploads/system/uploads/attachment_data/file/252885/NDNAD_Annual_Report_201213.pdf, pp. 23-24, accessed 6 November 2018.

'allied disclosure arrangements' were concluded. ${ }^{63}$ The law also allowed that, should the circumstances of evidence indicate that the DNA sample be needed for future retesting, or in cases of admissibility challenges, the chief investigating officer can apply to a district judge or the biometrics commissioner for an order to retain the sample for up to a maximum of thirty-six months.

The new retention criteria presented a range of operational, procedural and audit challenges. (1) How to ensure that, once a computerized profile has been produced, the original sample is destroyed? (2) How to ensure that profiles and their related samples (if retained) are deleted within six months of an investigation ending and no further action being taken? (3) How to ensure that arrangements are in place for earlier deletion and for longer retention of samples and profiles in certain prescribed circumstances? The biometrics commissioner readily admitted that he did not have the resources to systematically assure that the required changes had been implemented. The few visits that he made to police services did seem to reveal issues with delivery. He reported that while he was 'impressed by the openness which forces have shown me' it was evident that in some forces his visits had 'acted as a useful spur' to strengthen procedures for the retention and processing of DNA samples. ${ }^{64}$

While some implementation challenges were clearly operational, others were structural. One basic but important issue, for example, was how to determine when an investigation was closed: this required the development of formal guidance from the National Police Chiefs' Council (formerly the Association of Chief Police

63 Office of the Biometrics Commissioner, Annual Report 2016, at https://assets.publishing.service.gov.uk/ government/uploads/system/uploads/attachment_data/file/644426/CCS207_Biometrics_Commissioner_ARAprint.pdf, accessed 5 November 2018, p. 58.

64 Office of the Biometrics Commissioner, Annual Report 2015, at https://assets.publishing.service.gov.uk/ government/uploads/system/uploads/attachment_data/file/507104/54496_Biometrics_Commissioners_Report_ Print_Ready_3_.pdf, accessed 5 November 2018, p. 60. 
Table 3. Biometric retention periods as defined under the Protection of Freedoms Act 2012

\begin{tabular}{|c|c|}
\hline Individuals convicted of an offence & Fingerprint and DNA retention period \\
\hline $\begin{array}{l}\text { Adult convicted (including cautions, reprimands } \\
\text { and final warnings) of any recordable offence }\end{array}$ & Indefinite \\
\hline $\begin{array}{l}\text { Under-eighteen convicted (including cautions, } \\
\text { reprimands and final warnings) of a qualifying } \\
\text { offence }\end{array}$ & Indefinite \\
\hline Under-eighteen convicted of a minor offence & $\begin{array}{l}\text { 1st conviction: five years (plus length of any custodial } \\
\text { sentence), or indefinite if the custodial sentence is five } \\
\text { years or more. } \\
2 \text { nd conviction: indefinite }\end{array}$ \\
\hline \multicolumn{2}{|l|}{ Individuals not convicted of an offence } \\
\hline $\begin{array}{l}\text { Any age charged with but not convicted of a } \\
\text { qualifying offence }\end{array}$ & $\begin{array}{l}\text { Normally deletion within six months of the end of an } \\
\text { investigation } \\
\text { Three years plus two-year extension if granted by } \\
\text { district judge }\end{array}$ \\
\hline $\begin{array}{l}\text { Any age arrested for but not charged with a } \\
\text { qualifying offence }\end{array}$ & $\begin{array}{l}\text { Normally deletion within six months of the end of an } \\
\text { investigation } \\
\text { Three years if granted by biometrics commissioner plus } \\
\text { two-year extension if granted by district judge }\end{array}$ \\
\hline $\begin{array}{l}\text { Any age arrested for or charged with a minor } \\
\text { offence }\end{array}$ & $\begin{array}{l}\text { None but speculatively searched against National } \\
\text { DNA Database (NDNAD) and national fingerprint } \\
\text { database (IDENT1) }\end{array}$ \\
\hline Penalty notice for disorder & Two years \\
\hline
\end{tabular}

Source:

Adapted from ACRO Criminal Records Office reports.

Officers). ${ }^{65}$ Similarly, new software was developed so that samples taken could be quickly checked against the database, avoiding now illegal long-term retentions. In 2015, ACRO also launched a procedure for handling requests from the public for early deletion from the database.

Other issues have proved intractable. An enduring set of problems relates to the need to align forensic and police record computer systems so that profiles can be accurately retained or deleted at the appropriate times. Reports from the biometrics commissioner repeatedly discuss the difficulty of programming the PNC so that it could 'automatically drive' the deletion of arrestee records only and always according to the specified rules and time frame, and reflect on continued doubts as to whether entries onto the PNC were accurate and up to date. The biometrics commissioner has openly acknowledged that fully implementing the PoFA is consequently 'an impossible task' and that the records of thousands of people have been wrongly retained and that a smaller number of records have been wrongly erased:

65 National Police Chief's Council, 'Deletion of records from national police systems', 2015, at https://assets. publishing.service.gov.uk/government/uploads/system/uploads/attachment_data/file/430095/Record_Deletion_ Process.pdf. 
Given the pressures on police and other budgets and the need to prioritise resources, it is unsurprising that it was decided that the sensible course would instead be: to settle for a system which, though generally producing appropriate results, would sometimes lead to material being retained when it should in fact have been deleted; but to seek to mitigate the adverse effects of that 'compromise' arrangement by (among other things) providing detailed guidance to forces about checking the lawfulness of any matches with profiles or fingerprints on the national databases before acting on them. ${ }^{66}$

\section{Conclusion: the preservation of biovalue}

Some of the objections and delays to the implementation of the ECtHR ruling in the case of $S \&$ Marper v. UK (2008) related to the operational implementation and practicability of the erasures and deletions it required: some insiders raised doubts as to whether the existing storage system would allow selective profile deletions and also questioned whether, in the era of data sharing and backups, a record can ever be said to have fully disappeared. Given the existence of DNA as both bodily material and data double, and the capacity for sharing and copying within computerized systems, what constitutes the 'ending' of DNA records? Is it the destruction of a genetic sample, the deletion of all its digital traces, the loss of its accessibility through computer searches, or merely the taking away of its legal admissibility? While the PoFA has since been enacted, the implementation of existential, exceptional and everyday endings has in practice left some 'orphan' DNA which has officially disappeared but actually persists, albeit in a state of limbo that should make it unusable.

As the introduction suggests, the reconfiguration and shrinking of the NDNAD attracted relatively little public attention. This is intriguing because the biovalue of collections such as the NDNAD is largely anticipatory and rooted in promises about future utility. Despite the scale of the destruction of samples and deletions of records and the weight of promissory expectations associated with forensic genetics, surprisingly few stakeholders or commentators were prepared openly to voice concerns about the long-term consequences of existential and exceptional endings. Emerging forms of forensic science may create as yet unforeseen reasons why deletion of records and destruction of samples may one day be deemed to be short-sighted. For some supporters of the PoFA this potential for future exploitation was, on the contrary, a rationale for destruction:

As biological science develops rapidly, so the genetic and medical information that can be read from a person's DNA is growing year upon year. With this increased knowledge and information, the dangers of a government holding collections of DNA samples increases too. ${ }^{67}$

This rhetoric of future-proofing civil liberties is tempered in later documents with the language of proportionality and efficiency. Junior ministers and the NDNAD Strategy Board are keen to show how the truncation of the database had not lessened its effectiveness, citing year-on-year increases in the rate of matches to the database. Nonetheless we can see two contrary imperatives at play in this and other forms of biobanking: the

66 Office of the Biometrics Commissioner, op. cit. (64), p. 67.

67 Ministerial foreword to NDNAD Strategy Board report, December 2011. 
first is to ensure that data and samples that may be useful in the future are not lost; the second is to address issues of consent and privacy that may be compromised by inappropriate retention or repurposing.

From its inception to its current iteration, the NDNAD transformed from a collection of genetic samples to a computerized collection of genetic profiles. We could interpret the destruction of samples and the deletion of many profiles during this transition as sacrifices to preserve the overall biovalue of the NDNAD, saving it from further political and legal scrutiny under an evolving ethical regime. As we have seen, however, ethical questions interact in complex ways with questions of practical utility and economic costs and benefits. For example, it is debatable whether nearly eight million samples were destroyed because of their latent potential, because of their apparent lack of current usefulness, or because they cost ninety pence each per annum to store. Similarly, the operation of the new regime of exceptional and everyday ending of profiles from the database is an imperfect work in progress, some way short of the neat procedural changes outlined in legislation. Nevertheless, changes to the NDNAD have, at least in the short term, closed debate about its legitimacy, temporarily securing the continued existence of the overall collection. The biovalue of the database has been maintained whilst sidestepping other potentially contentious issues, notably whether it is proportionate to retain indefinitely the DNA records of adults convicted of any criminal offence. New powers such as the Anti-social Behaviour Crime and Policing Act 2014 have expanded the retention regime once more. Just as significantly, the cumulative acquisitive logic of the revised inclusion criteria meant that by 2016 over five million people had profiles on the NDNAD; this figure is higher than when the ECtHR made its ruling in 2008.

A series of developments mean that the current stabilization of the NDNAD may not last long. In 2012 the government broke up the Forensic Science Service and privatized and outsourced its work. A number of recent scandals have undermined public confidence in the reliability of forensic science in the resulting commercialized climate. ${ }^{68}$ Moreover, new analytical techniques, for example using Y-chromosome markers and using trace or 'touch' DNA (with its implications for the analysis of mixed-trace profiles containing DNA from two or more persons), may require new ways of recording, storing

68 The most discussed recent case - as reported by The Guardian, The Independent and other UK media outlets in 2017 - concerned the alleged manipulation of forensic data in 10,000 instances, since 2012, by Trimega and its owner, Randox, commercial providers of forensic science services to police forces in the UK: e.g. Nazia Parveen, 'Manchester lab's drug tests may have been manipulated', The Guardian, 19 February 2017, at www.theguardian.com/uk-news/2017/feb/19/manchester-lab-randox-drink-drug-tests-toxicologymay-have-been-manipulated, accessed 2 May 2019; Hannah Devlin and Vikram Dodd, 'Police review 10,000 cases in forensics data "manipulation" inquiry', The Guardian, 21 November 2017, at www.theguardian. com/uk-news/2017/nov/21/forensics-data-manipulation-may-have-affected-10000-cases, accessed 2 May 2019; Lizzie Dearden, 'Convictions in doubt as more than 10,000 cases could be affected by data manipulation at forensics lab', The Independent, 21 November 2019, at www.independent.co.uk/news/uk/crime/forensic-labsdata-manipulation-criminal-convictions-doubt-randox-testing-services-investigation-a8066966.html, accessed 2 May 2019; BBC News, 'Randox forensics inquiry: police suspend drug-test contracts', 27 November 2017, at www.bbc.co.uk/news/uk-england-manchester-42144231, accessed 2 May 2019. Events prompted discussion in the House of Lords on 27 November, as reflected in Hansard, 'Randox and Trimega Laboratories', 27 November 2017, vol. 787, UK Parliament, at https:/hansard.parliament.uk/Lords/2017-11-27/debates/ C70A3F27-2CEE-4ED2-959D-DB853DDB2175/RandoxAndTrimegaLaboratories, accessed 2 May 2019. 
and profiling DNA. Controversially, police officers are also increasingly considering the use of genetic material and data collected for other reasons, such as commercial genealogy or health testing, in their investigations. This move to utilize DNA originally donated and curated outside a criminal-justice context potentially sidesteps the requirement for a stand-alone dedicated and managed police forensic database; it also disrupts established conventions of ethico-legal governance around DNA donation and collection. ${ }^{69}$

The potential future exploitation of other genetic collections is one example of a wider phenomenon: developments open up opportunities for the sharing and repurposing of data across institutional and scientific domains and the multiplication of different reference databases. This potentially challenges the boundaries, coherence, singularity and integrity of the NDNAD, upon which much of its operation and governance have previously been predicated. This is an issue given increasing priority by the UK biometrics commissioner, who seeks to broaden his remit to cover other (increasingly interconnected) policing databases, including the facial image database which currently holds almost twenty million images. This throws into sharp relief the 'genetic exceptionalism' evident in much of the past legal, ethical and political discourse around the NDNAD. As discussed earlier, some claim that this exceptionalism lies in the capacity of DNA to defy the categorical boundary between bodily material and bodily information. Yet the sample/profile distinction, however confounding, has been central to the changes we have described. The nature of an ending - along the continuum from crisis to conventional - depends on the registers within which it is enacted. It is important to cultivate curiosity about the relationships between and affordances of different modes of materialization, and the labour and tensions inherent in the combination and translation between these bodily and digital registers of bioinformation.

69 See, for example, J.W. Hazel, E.W. Clayton, B.A. Malin and C. Slobogin, 'Is it time for a universal genetic forensic database?', Science (November 2018) 362(6417), pp. 898-900. 